\title{
Technological solutions applied in biogas plants - a case study
}

\author{
Daniel Chludziński ${ }^{1, *}$, Michat Duda ${ }^{1}$ \\ ${ }^{1}$ University of Warmia and Mazury in Olsztyn, Department of Electrical Engineering, Power \\ Engineering, Electronics and Automation, Oczapowskiego 11, 10-736 Olsztyn, Poland
}

\begin{abstract}
This paper describes three operating biogas plants with a comparable electrical power of $600 \mathrm{~kW}$. The plants are situated in Germany and were constructed between 2007 and 2013. They belong to one owner who has a farm with an area of ca. 1,200 ha, oriented towards plant production. The article presents technological solutions applied in biogas plants; an attempt was also made to determine their effect on the amount of electricity consumed in the process (operation of stirrers, substrate feeders, pumps, control systems, lighting, etc.). Despite similar electrical power, the biogas plants differ in terms of construction and technological solutions. The differences stem mainly from the number and capacity of digestion chambers, the method of biomass stirring and the method of substrate supply. The preliminary conclusions from observations of these facilities confirm the literature data concerning the consumption of electricity in the process compared to total electricity production. The paper also presents the capacity factor for each facility and the level of heat use from cogeneration.
\end{abstract}

\section{Introduction}

Restrictions regarding emission of greenhouse gases to the atmosphere will be tightened in the future. Therefore, many countries follow policies oriented towards replacing fossil fuels with renewable energy sources, with simultaneous implementation of energy-saving technologies [1].

Production of agricultural biogas is one of the methods for generation of energy from renewable sources. Biogas is a product of anaerobic digestion of organic substances containing carbohydrates, proteins, starch and cellulose. It is obtained from biomass, especially in installations of animal or plant waste processing at wastewater treatment plants and landfill sites [2]. Biogas is mainly used in heat and power generation processes in CHP (combined heat and power) cogeneration systems. A CHP unit can achieve a total efficiency of $75-85 \%$ (energy generation efficiency $36-40 \%$, heat generation efficiency 43-53\%) [3]. Biogas can also be used in local gas supply networks and in transport [4]. Biogas can be produced from plant materials, such as maize silage, grass, rye silage, ground grain, as well as production waste, such as liquid manure or manure. Waste from food industry, dairy plants, sugar factories, paper factories and from meat processing plants is

* Corresponding author: daniel.chludzinski@uwm.edu.pl 
a separate category of substrates [5]. Data on substrates used in the production of biogas are published in so-called "substrate atlases", which present over 200 organic substances, described in regard to their use in biogas production [6]. In most cases, agricultural biogas plants use several substrates, depending on their price and availability on the local market [7]. Germany is the leader in developing biogas plants (8,928 agricultural biogas plants were in operation in 2015) [8]. Despite having great potential (14.6 million ha of agricultural land and well-developed breeding of cattle and pigs), there were only 93 installations in Poland in Q1 2018 [1,9]. It is noteworthy that electricity generated in biogas plants is very stable compared to that obtained from wind farms or photovoltaic cells, which are highly dependent on weather conditions [8]. Raw material supply to digestion chambers is the only condition that must be met to ensure the continuous operation of a biogas plant. This makes the location of a biogas plant very important; it must guarantee a proper amount of raw materials and minimise the cost of its transport [7]. Agricultural biogas plants are a stimulating factor in developing highly promoted dispersed power generation because it improves the energy security in the area where it is used [10].

Agricultural biogas plants not only produce, but also use electricity in the process, e.g. to power stirrers. Mechanical stirring of the charge is the most common stirring system applied in $85-90 \%$ of working biogas plants [11]. There are also other methods of stirring charge in a digestion chamber: hydraulic, pneumatic and hybrid. The aim of stirring biomass in digestion chambers is to ensure the uniform process of fermentation in the whole volume of the charge. Stirring improves access of bacteria to the newly added substrate, which results in improving the intensity of the digestion process [12].

\section{Characterisation of selected agricultural biogas plants}

Three agricultural biogas plants put into use in 2007-2013 are described below. These are installations of similar electrical power: 610,610 and $590 \mathrm{~kW}$. They belong to one owner who has a farm with an area of ca. 1,200 ha. The farm is oriented towards plant production, which guarantees a sufficient amount of substrate and the possibility of using the digestate to supplement minerals in the tilled land. Agricultural waste comes from the neighbouring farms, such as porcine liquid manure, bovine manure and turkey manure.

\subsection{Biogas plant no. 1 (conventional)}

Biogas plant no. 1 was put into use in 2007. Its main elements include two digestion chambers, each with a capacity of ca. $1,300 \mathrm{~m}^{3}$ (diameter $18 \mathrm{~m}$, height $6 \mathrm{~m}$ ) and the postdigestion chamber with the capacity of $1,300 \mathrm{~m}^{3}$. The charge in the chambers is stirred periodically by 6 side mechanical rod stirrers (there are 2 stirrers in each chamber). A chamber with a side rod stirrer is shown in Fig. 1. The process of biogas production starts with supplying the substrate to digestion chambers. In this biogas plant it is done with an automatic screw feeder. The feeder is started every 30 minutes. Excess charge from the digestion chambers flows to the post-digestion chamber, from where it passes to the separator in order to remove liquid from the post-digestion charge. The charge stays in the digestion chambers for 40 days, on average. Biogas produced in the fermentation chambers is purified and then burned directly in two engines of the cogeneration system. The produced electricity is sold to the power supply system. Ca. $85 \%$ of heat from the cogeneration system is used to heat the nearby farm buildings, the grain drier (seasonally), the asparagus plantation and it is used to maintain a constant temperature in the chambers. 


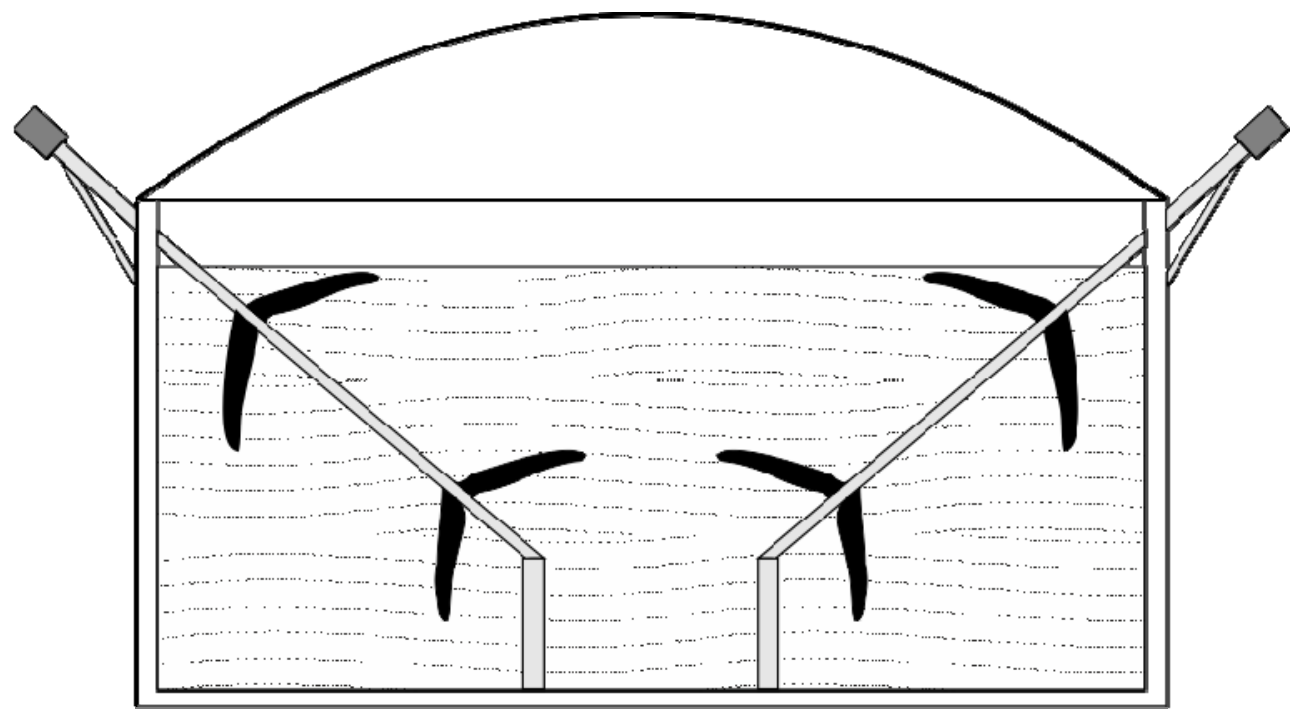

Fig. 1. Side mechanical stirrer in a digestion chamber.

Substrates used in a biogas plant include: maize silage, rye silage and 1 tonne of ground grain every day. Digestate is used on the farm as fertiliser.

\subsection{Biogas plant no. 2 (sprinkling system)}

This biogas plant was put into use in 2011. Its main elements include two digestion chambers, each with a capacity of ca. $5,000 \mathrm{~m}^{3}$ (diameter $38 \mathrm{~m}$, height $6 \mathrm{~m}$ ). No mechanical stirring is applied in the digestion chambers. The contents of the digestion chambers is stirred by four sprinkling nozzles "Beregnungsdüse" placed in the upper part of the tank. A sprinkling nozzle is shown in Fig. 2. The system was developed by a German company SAUTER.
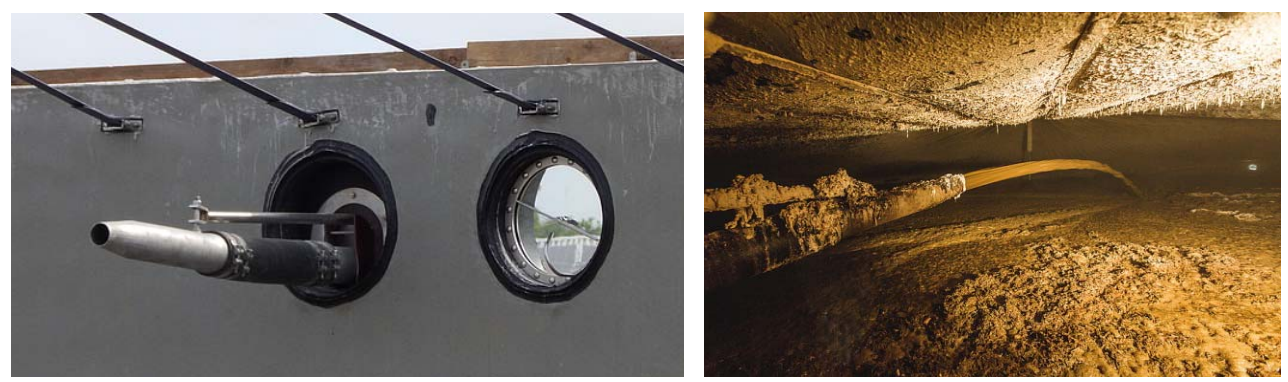

Fig. 2. A sprinkling nozzle (source: http://www.sauter-biogas.de).

The biogas plant with a sprinkling system is not equipped with a heating system which, as a rule, is placed inside the digestion chamber. In this case, the substrate is heated by an external heat exchanger installed in the circulation of the pump which feeds sprinkling nozzles. A diagram of a biogas plant with a sprinkling system is shown in Fig. 3. 


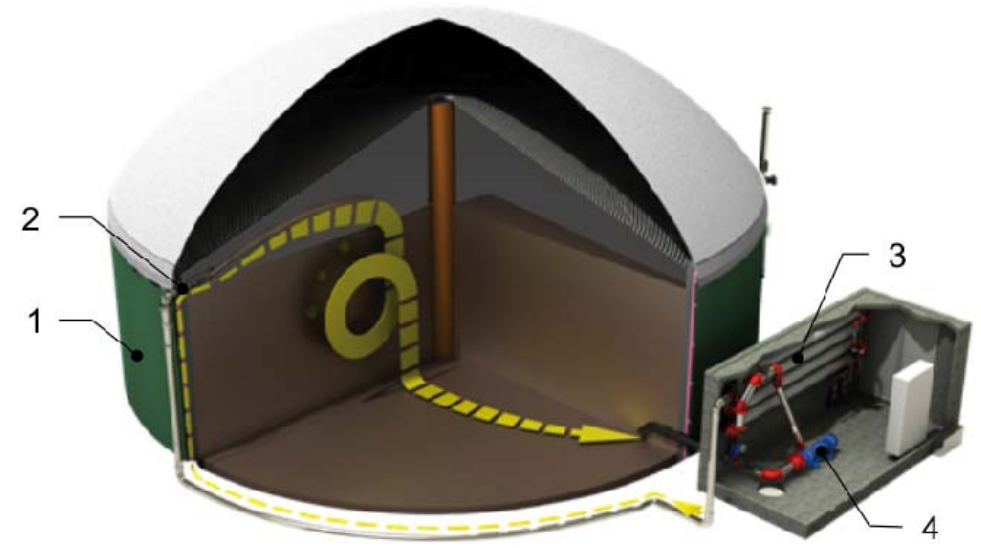

Fig. 3. A diagram of a biogas plant with a sprinkling system: 1-digestion chamber, 2-sprinkling nozzle, 3-heat exchanger, 4-pump feeding the sprinkling nozzles (source: http://www.sauter-biogas.de).

There is no automatic substrate feeder in a biogas plant with a sprinkling system. A charge is supplied through a special channel, where a feeder is used to feed substrate to the digestion chamber. The system is very flexible and allows for up to 3-day breaks in substrate supply. A loading channel is shown in Fig. 4.

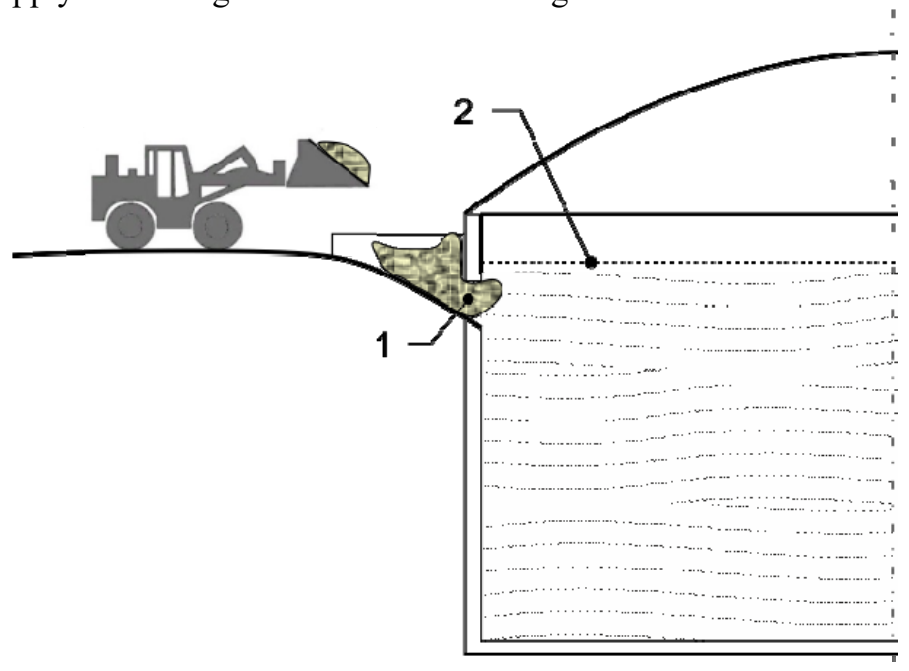

Fig. 4. The feeding channel of a digestion chamber with a sprinkling system: 1-feeding channel, $2-$ the level of the substrate in the digestion chamber.

Owing to the large size of the digestion tanks, the substrate can remain in the chambers for a long time; in consequence, poor quality substrate can also be used. The high cost of construction of large capacity digestion chambers is an obvious drawback of this system. In this case, the capacity of one chamber is larger than that of three chambers of the biogas plant no. 1 of a similar electrical power.

Biogas produced in the digestion chambers is burned in two engines of the cogeneration system. The produced electricity in sold to the power supply system. Ca. $90 \%$ of heat from the cogeneration system is used to heat the pig sty with piglets (ca. 11,000), in the grain drier and to heat two detached houses. Substrates used in the biogas plant include: $30 \mathrm{~m}^{3}$ of porcine liquid manure (every day), sorghum silage, grass silage, rye silage and small amounts of maize silage. 


\subsection{Biogas plant no. 3 (EnergyJet system)}

Biogas plant no. 3 was put to use in 2004. In 2013, its owner changed and it underwent a thorough modernisation. Its main elements include a digestion chamber with a capacity of ca. $1,300 \mathrm{~m}^{3}$ (diameter $18 \mathrm{~m}$, height $6 \mathrm{~m}$ ) and the post-digestion chamber with the capacity of $1,600 \mathrm{~m}^{3}$ (diameter $20 \mathrm{~m}$, height $6 \mathrm{~m}$ ). A mechanical stirring system is applied in the installation (side-rod stirrers and an immersible stirrer). A substrate is fed to the digestion chamber with an automatic feeder (a system with a moveable wall). The substrate from the feeder is transferred to the EnergyJet supply system, manufactured by Vogelsang. A diagram of the EnergyJet system is shown in Fig. 5. In the EnergyJet, a platform auger transports substrate from the feeder to the zone in which the liquid phase (recirculate) is added continuously under pressure. The liquid phase and the substrate form a uniform suspension, which is subsequently pumped to the digestion chamber. In this system, solid substrates, such as maize silage, grass silage, whole plant silage and manure are cut up and fed wet to the digestion chamber. Biogas produced in the digestion chambers is burned in two engines of the cogeneration system. The produced electricity is then sold to the power supply system. Ca. $75 \%$ of heat from the cogeneration system is used in the grain drier and to heat a workshop and a detached house. Substrates used in the biogas plant include: maize silage, bovine manure, turkey manure and maize grain.

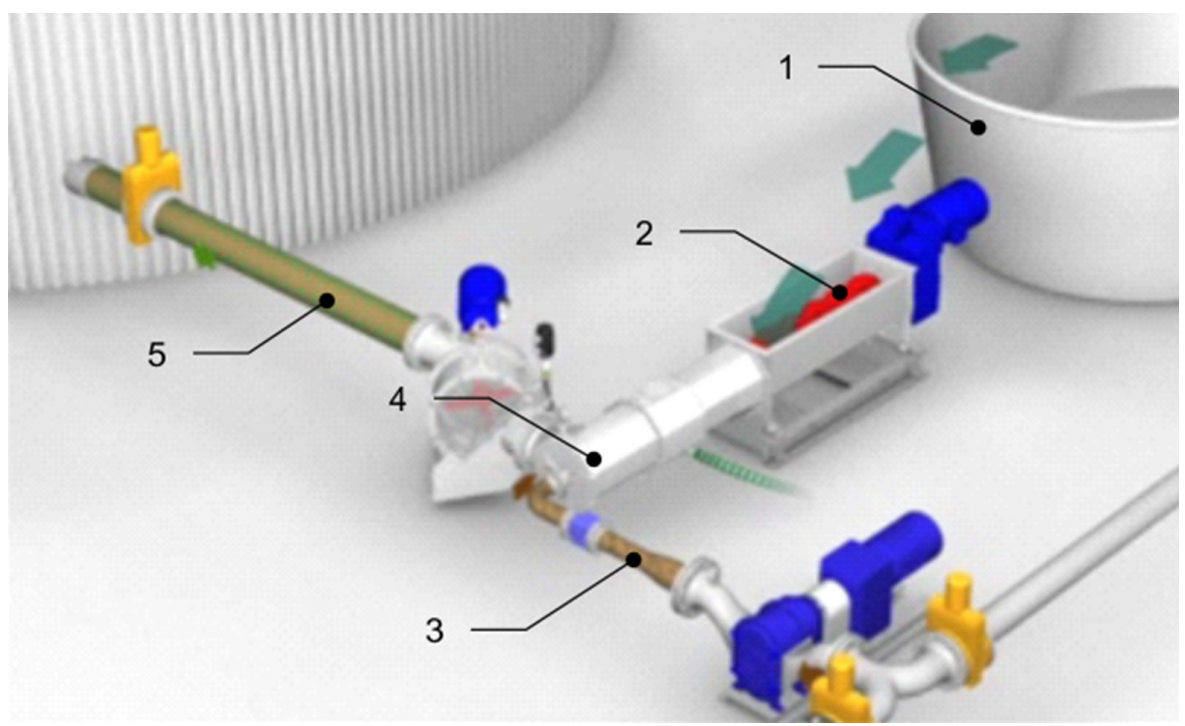

Fig. 5. A diagram of feeding substrate in the EnergyJet system: 1-automatic feeder, 2-platform auger, 3-feeding re-circulate under pressure, 4-zone of mixing recirculate with substrate, 5-mixture of recirculate and substrate fed to a digestion chamber

(source: https://www.youtube.com/user/VogelsangChannel/videos).

\section{Generation of electricity}

Gross production of electricity in 2016 in the three agricultural biogas plants described above is shown in Fig. 6. Gross production of electricity means that the electricity consumed by the process is not included.

The data shown in Fig. 6 indicate that the operation of biogas plant no. 2 (BG 2) was the most stable. It is a biogas plant with a sprinkler system, with the largest capacity of the digestion chambers. The lowest electricity output was noted in biogas plant no. 3 (BG3). 
It is a biogas plant with the EnergyJet system with the digestion chambers of the smallest capacity. Large differences in electricity production in individual weeks are mainly related to the removal of failures and maintenance of equipment.

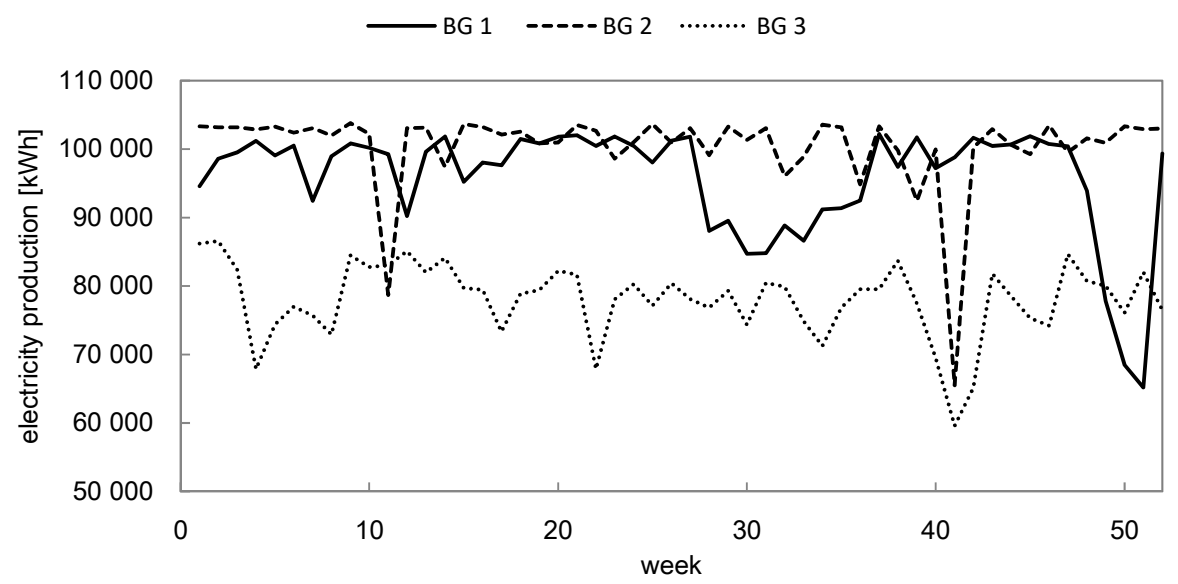

Fig. 6. Gross electricity production in individual weeks of 2016.

According to literature data, electricity consumption in the process accounts for an average of $9 \%$ of produced electricity [5]. Table 1 shows the gross annual electricity output, electricity consumption in the process and gross electricity production.

Table 1. Annual electricity output in the biogas plants 2016 (own elaboration based on data provided by the owner of the objects).

\begin{tabular}{|c|c|c|c|}
\hline Parameters & $\begin{array}{c}\text { Biogas plant } \\
\text { No. 1 }\end{array}$ & $\begin{array}{c}\text { Biogas plant } \\
\text { No. 2 }\end{array}$ & $\begin{array}{c}\text { Biogas plant } \\
\text { No. 3 }\end{array}$ \\
\hline Electrical power installed $[\mathrm{kW}]$ & 610 & 610 & 590 \\
\hline Electricity production, gross $[\mathrm{kWh} /$ year] & $4,984,037$ & $5,221,297$ & $4,059,947$ \\
\hline Electricity consumption by the plant [kWh/year] & 490,974 & 350,102 & 266,473 \\
\hline Net electricity production $[\mathrm{kWh} /$ year] & $4,493,063$ & $4,871,195$ & $3,793,474$ \\
\hline Electricity consumption by the plant [\%] & $\mathbf{9 . 9}$ & $\mathbf{6 . 7}$ & $\mathbf{6 . 6}$ \\
\hline Capacity factor [\%] & $\mathbf{9 3 . 5}$ & $\mathbf{9 8 . 0}$ & $\mathbf{7 8 . 8}$ \\
\hline
\end{tabular}

The data in Table 1 were used to calculate that biogas plant no. 1 consumes in the process $9.9 \%$ of the electricity that it produces. Meanwhile, biogas plants no. 2 and 3 consume less electricity in the process than the average value mentioned in the literature 6.7 and $6.6 \%$, respectively.

Assuming theoretically that the amount of electricity consumed in biogas plant no. 1 will be decreased from $9.9 \%$ to ca. $7 \%$, approximately $140,000 \mathrm{kWh}$ could be saved annually.

When analysing production of electricity in the biogas plants presented in this paper, one should take note of the high capacity factor (Table 1). It is the highest in biogas plant No. $2-98 \%$ and the lowest $-78.8 \%$ - in biogas plant No. 3 in 2016. The capacity factor is much lower for other renewable energy sources. The capacity factor in wind farms is $15 \%$ and $25 \%$ for on-shore and off-shore farms, respectively. It is ca. $30 \%$ for a hydroelectric power plant and ca. $12 \%$ for a photovoltaic installation [2]. 


\section{Conclusions}

The analysis has shown that the technological solutions applied in agricultural biogas plants have a direct impact on electricity consumption in the process itself. According to literature data, biogas plants operating in cogeneration use ca. $9 \%$ of the produced electricity in the process (operation of stirrers, substrate feeders, pumps, control systems) [5]. The share of such energy in two of the biogas plants presented in this paper was lower than the average $6.7 \%$ and $6.6 \%$. The value was higher than average in the third facility $-9.9 \%$. Differences in energy consumption by individual biogas plants are related to the method of stirring charge in digestion chambers, feeding substrate and the size of the digestion chambers.

The data presented here confirm the high value of the capacity factor compared to other RES installations, such as wind farms or photovoltaic installations. The capacity factor in the biogas plants presented here was: $93.5 \%, 98.0 \%$ and $78.8 \%$.

It is important in agricultural biogas plants operating in cogeneration that a concept of how heat will be utilised should be developed by the design stage. Utilisation of heat will allow a plant to achieve high total efficiency. From $75 \%$ to $90 \%$ of heat from cogeneration was utilised in the analysed biogas plants. The absence of a concept for heat utilisation may significantly reduce the profit generated by biogas plants or - in extreme cases - it can make the project unprofitable.

\section{References}

1. A. Piwowar, M. Dzikuć, J. Adamczyk, Renew. Sust. Energ. Rev. 58, 69-74 (2016)

2. A. Wantuch, M. Janowski, Control, Measurement in Economy and Environment Protection, 4(4), 105-108 (2014)

3. Biogasgewinnung und nutzung, FNR, Gülzow, (2006)

4. W. Gostomczyk, (Stan i perspektywy rozwoju rynku biogazu w UE i Polsce - ujęcie ekonomiczne, Zeszyty Naukowe SGGW w Warszawie - Problemy Rolnictwa Światowego, 17(32), no. 2, 48-64, 2017)

5. A. Curkowski, A. Oniszk-Popławska, Czysta Energia, 1, 25-27 (2010)

6. Online European Feedstock Atlas basis version, http://daten.ktbl.de/euagrobiogasbasis/ navigation.do?selectedAction=Startseite

7. B. Igliński, R. Buczkowski, M. Cichosz, Rynek Energii, 3(118), 93-101 (2015)

8. M. Czop, E. Kłapcia, Engineering and Protection of Environment, 20(1), 5-16 (2017)

9. Rejestr wytwórców biogazu rolniczego, http://www.kowr.gov.pl/

10. R. Szczerbowski, B. Ceran, Polityka energetyczna, 16, (2013)

11. S. Marks, A. Jezowska, K. Kozlowski et al., Technika Rolnicza Ogrodnicza Leśna, 6, (2017)

12. A. Curkowski, A. Oniszk-Popławska, P. Mroczkowski et al., (Praca na zlecenie Ministerstwa Gospodarki, 2011) 